\title{
足部の精密化と目的関数の混成化による歩行シミュレーションモデルの開発*
}

\author{
林 祐一郎 ${ }^{* 1}$, 長谷 和徳 ${ }^{* 1}$, 内藤 尚*2, 西澤 教之*3
}

\section{Development of a walking simulation model based on the hybridization of the objective function and the precise foot segment model}

\author{
Yuichiro HAYASHI ${ }^{*}{ }^{1}$, Kazunori HASE, Hisashi NAITO and Noriyuki NISHIZAWA \\ *1 Tokyo Metropolitan Univ. Dept. of Mechanical Engineering \\ 1-1 Minami-Osawa, Hachioji-shi, Tokyo, 192-0397 Japan
}

\section{Received 26 October 2013}

\begin{abstract}
Neuro-musculo-skeletal model has been developed that is capable of generating reasonable gait. However, the details of the ground reaction force waveform differ from real gait motion quantitatively. A whole-body walking model including the detailed foot model has not been proposed and a unified objective function has not been proposed. Therefore, the purposes of this study are to improve a forward dynamic walking simulation by developing a precise foot model and making a hybrid criterion for the generation of human gait motion by using the application and utilization of genetic algorithm for the optimized calculation. The dynamics of the human body has been represented by 22 three-dimensional rigid links with 78 muscles and 62 neural oscillators. Unknown neuronal parameters have been adjusted by a numerical search method using the evaluative criterion for locomotion that is defined by the locomotive energy efficiency, the toe clearance and the magnitude of the ground reaction force. As a result of adjustment of the neuronal parameters, walking 10 steps has been generated. The simulated walking pattern has closely agreed with actual human walking not only of joint movement but also of the mutual conversion of the mechanical energy and the magnitude of the ground reaction force.
\end{abstract}

Key Words : Foot segment model, Locomotive energy efficiency, Walking and gait, Neuro-musculo-skeletal system, Numerical simulation, Genetic algorithm, Biomechanics

\section{1. 緒言}

歩行などの身体運動は，神経系により制御される筋活動，身体の動特性および重力によってなされる。これま でに開発されてきた神経筋骨格モデル(長谷他，2000)での順動力学歩行シミュレーションでは，身体形態と神経 振動子による筋活動により，3 次元空間における定常歩行の再現が可能であり，おおむね妥当な歩容を生成でき る。そして，それらにより，生体力学的な観点において重要となる身体形態の変化が歩容に及ぼす影響を予測可 能となった。しかし，従来のモデルでは多くのシミュレーションモデルがそうであるように，足部の簡略化や床 反力波形が実際の通常歩行に生じる特徵を必ずしも表現し得ていないなど，細部を見ると依然として精度が不十 分であると考えられるため，現存する歩行モデルの妥当性を向上させる必要がある。ここで，歩行モデルの精度 向上には神経制御モデルも含め多種多様な視点が考えられるが, 中でも足部の精密化に焦点を当てることとする.

足部は 26 種類の関節と 54 種類の骨を有する複雑な構造体であり，機能として立脚安定性や衝撃吸収など重要 な役割を果たしている上，特に縦アーチなどの関節構造的特徴を持っており，その力学的挙動は全身歩容全体に 影響を及ぼすものと考えられる。ささらに，足部は歩行中にその形状を変えるが，ヒト以外の動物で足部にア一チ 構造を有する動物は存在しない(長谷他，2000；木村，木村，2002). ヒトの一歩行周期中の立脚期後期における足 部は片持ち梁構造となるため，床反力によって生じるトルクが大きくなり，最大角度変化を生じる。この足部負

\footnotetext{
*論文 No.13-00777 [DOI: 10.1299/transjsme.2014dr0099]

${ }^{* 1}$ 正員, 首都大学東京大学院 理工学研究科 機械工学専攻（广192-0397＼cjkstart東京都八王子市南大沢 1-1）

*2 正員，金沢大学 理工研究域 機械工学系（下920-1192 石川県金沢市角間町）

*3 首都大学東京大学院 理工学研究科 機械工学専攻

E-mail: hayashiy@tmu.ac.jp
} 
荷に抗する最も顕著な構造はアーチ構造であり，抗重力機構として捉えられるなど足部の形状とその変化が歩行 全体に影響を及ぼすものと考えられるが，アーチの存在意義が定量的に確認された事実は少なく(Xiang, et al., 2010), ア一チの有無による意義を解明しなければならないと考えられる. また，歩行を最適化するための統一的 な単一の目的関数はこれまでに存在していない(木村, 木村, 2002)ことから, 複数の目的関数を組み合わせるこ とで実歩行を再現できると考えられる.

そこで, 本研究ではこれらを達成可能にすると考えられる足部精密モデルを導入し, 目的関数を混成化するこ とによって生体力学的に妥当な歩行シミュレーション技術を開発する.

\section{2. 神経筋骨格系を有する 2 足歩行モデル}

\section{$2 \cdot 1$ 全身モデル}

全身のシミュレーションモデルは長谷のモデル(長谷他, 2000)を拡張し, 慣性特性や関節自由度を剛体リンク モデルで表現しており，図１に筋骨格モデルを示す，モデルは下肢（大腿部，下腿部，足部，足趾部）, 骨盤部， 腰部下部，腰部上部，頭胸部および上肢（上腕部，前腕部）から構成される．股関節および腰部下部関節は回転 の 3 自由度を有しており，肩関節と足関節は内外転と屈伸の自由度を持つ関節とした．なお，その他の関節は回 転の 1 自由度とした. よって, 身体モデルは空間に対する運動の 6 自由度と関節運動の 31 自由度を持つ 22 節の 剛体リンクと合計 78 の筋肉をモデル化した. また, 足趾の筋は屈曲と伸展の回転自由度に対応するように, 長母 趾屈筋，長母趾伸筋，長趾屈筋，長趾伸筋などを付加した.

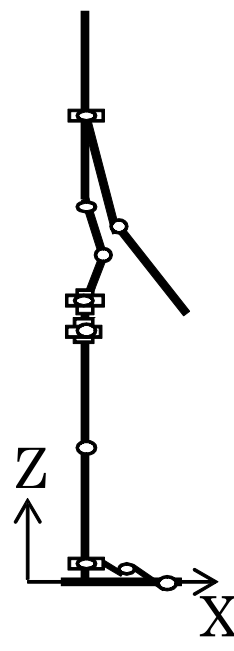

(a) 22-rigid-link model

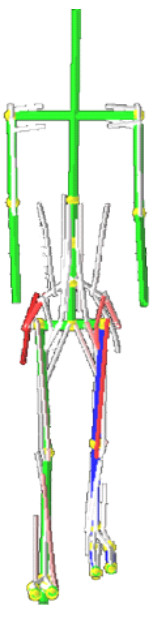

(b) Musculo-skeletal model

Fig. 1 Three dimensional full human body simulation model. In the coordinate system, x, y, z-axes are anterior, lateral and vertical directions. Degree of freedom in the joints is expressed by rigid link model as the numbers.

\section{$2 \cdot 2$ 足部モデル}

本研究では，足部を足首から末節趾に至る下肢の一部分と定義した．ここで，ヒトの足部は 5 本の足趾から構 成されるが, 本モデルでは計算コストを短縮した上で左右の安定性を保つように最小となる 2 本の足趾を表現し てモデル化した．これは，5 本の場合では母趾以外の足趾の質量と慣性モーメントが他の関節部位に対して非常 に小さいために数值積分における差分間隔を小さくしなければ計算が発散しやすくなること, また 1 本の足趾に つきアーチ部を含めて 2 自由度ずつ関節の自由度を付加すると両足で 20 自由度を有し, 慣性項の逆行列を計算 する際に自由度の二乗に比例した時間がかかり, 計算コストが増大するためである. 足趾 1 を第 1 趾と第 2 趾 の複合体, 足趾 2 を第 3 趾, 第 4 趾と第 5 趾の複合体と定義した. ここで, 本研究において提案するこれらの 足部モデルの単純化に関して，足部がヒトの歩行に及ぼす機能の観点からの裏付けとして述べるとすれば，提案 するモデルにおいて定義する足部の主要な距腿関節(Talocrural joint), 距骨下関節(Subtalar joint), 距舟関節 (Talonavicular joint), 踵立方関節(Calcaneocuboid joint), 中足趾節関節(Metatarsophalangeal joint)のうち, 距腿関節で は主に足首の背屈と底屈, 距骨下関節では内反と外反が行われ, 距舟関節と踵立方関節の 2 種類は互いに協調的 
に機能し足部全体の回内と回外の肢位の大部分を占め, 中足趾節関節は足部を固定することで歩行中の足先離地 を補助するというように, 各関節が足部の運動における重要な役割をそれぞれ担っている. しかし, 足部の中央 部に当たる中足部での特有な運動はあまりなく, 足趾の開帳運動に応じた弱い開帳が行われる程度である(鈴木他, 1999)ことから，後述する図 2 に示すように中足部のモデル化を省略し，該当する部分全体を 2 本の足趾で近似 的に表現したものとする.

さらに，中足部と末節部の足部接地精度を高めるために，内側緃アーチと外側緃アーチをそれぞれ距舟関節と 踵立方関節で表現し，それぞれ屈曲伸展の自由度を加えた，そして，足先離地を促すために，末節部の屈曲伸展 を行う中足趾節関節を設けた。詳細な足部モデルを図 2 に示寸. 図 2 において, 丸印で示しているものが足部の 床面との接触点である. 次節では, 踵に 3 力所, 前足部に 4 ケ所の接触点を定義し, 床面をバネとダンパからな る粘弾性力で表すことにより, 床反力を接地点の変位と速度から計算する.

足部モデルにおける各関節受動抵抗を考慮することに関して, 足部アーチに関する距舟関節と踵立方関節の関 節受動抵抗值は高嶋ら(高嶋他, 2003)を参考にした. 一方, 前足部の関節受動抵抗は計測值が存在しないため, 逆動力学解析を用いて推定した. 前足部固定モデルでの順動力学的歩行シミュレーションデータの前足部関節に 計測值(Kirsten, 2003)を代入し, 屈曲と伸展のそれぞれの最大角度時において関節に生じるトルクと関節受動抵抗 がつり合うように関節受動抵抗の係数值を試行錯誤的に求めた.

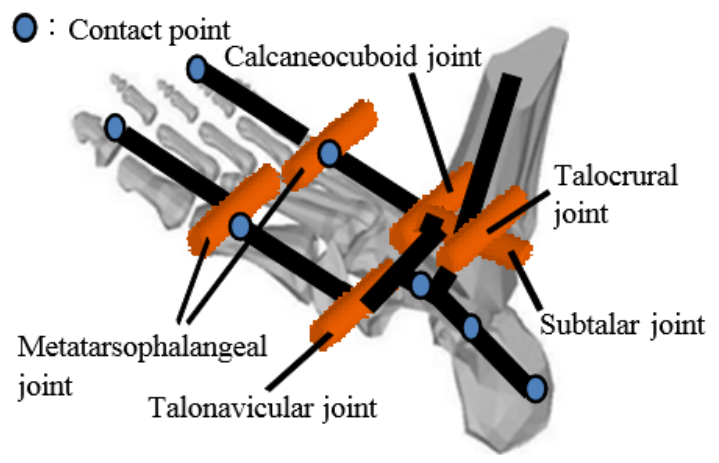

Fig. 2 Proposed precise foot segment model. Foot segment is modelled by expressing minimized two toes and defined contact points to contact the floor surface and connect the joints.

\section{$2 \cdot 3$ 床反力計算方法}

ヒトの歩行には両脚が地面に接地する両脚支持期が存在し，この両脚支持期では，脚と地面とで閉ループ構造 となるため力学的には内部不静定問題となる. また, 足部に複数の接触点がある場合でも内部不静定問題となる. 閉ループ構造では, 運動の自由度に対して拘束条件が存在し，通常のアルゴリズムでは単脚支持期と両脚支持期 から構成される運動方程式を解けない. そのため, 本研究では床反力值の算出をペナルティ法(Moore and Wilhelms, 1988; McKenna and Zeltzer, 1990)を用いて行った．ペナルティ法では床面を図 3 のようなバネとダンパからなる粘 弾性力で表すことにより, 床反力は接地点の変位と速度から計算可能となり, 開ループ構造と同様に扱えるので, 通常の運動方程式の解法が利用できる.

ただし, 粘弾性モデルでは床面に足部がめり込むため, 多少不自然な挙動になってしまうことや, めり込み量 を少なく寸るためにかなり大きな粘弾性係数を設定する必要がある. それにより, 数值計算を行う際に差分間隔 を小さく設定しなければならないため, 計算コストが増大寸るという欠点を持つ. しかし，ラグランジュ乗数を 用いる方法などと比較して簡単な計算方法により床反力を計算できる利点があり, 本研究では床反力を以下に示 すような線形の粘弾性体により記述する.

$$
\begin{aligned}
f_{x, k}^{E} & = \begin{cases}-k^{E}\left(x_{k}^{E}-x_{k}^{E 0}\right)-\alpha c^{E} \dot{x}_{k}^{E} & \left(z_{k}^{E} \leq 0\right) \\
0 & \left(z_{k}^{E}>0\right)\end{cases} \\
f_{y, k}^{E} & = \begin{cases}-k^{E}\left(y_{k}^{E}-y_{k}^{E 0}\right)-\alpha c^{E} \dot{y}_{k}^{E} & \left(z_{k}^{E} \leq 0\right) \\
0 & \left(z_{k}^{E}>0\right)\end{cases}
\end{aligned}
$$




$$
\begin{aligned}
& f_{z, k}^{E}= \begin{cases}-k^{E}\left(z_{k}^{E}-z_{k}^{E 0}\right)-\alpha c^{E} \dot{z}_{k}^{E} & \left(z_{k}^{E} \leq 0\right) \\
0 & \left(z_{k}^{E}>0\right)\end{cases} \\
& \alpha=\left\{\begin{array}{cl}
\left|z_{k}^{E} / 0.01\right| & \left(0 \geq z_{k}^{E}>-0.01\right) \\
1 & \left(z_{k}^{E}<-0.01\right)
\end{array}\right.
\end{aligned}
$$

ここで, $f_{x, k}^{E}, f_{y, k}^{E}, f_{z, k}^{E}$ は第 $k$ 番目の外力の $x$ 軸 (進行方向), $y$ 軸(左右方向), $z$ 軸方向成分(鉛直方向), $k^{E}$ は 弾性係数 $(=15000[\mathrm{~N} / \mathrm{m}]), c^{E}$ は粘性係数 $(=500[\mathrm{~N} \cdot \mathrm{s} / \mathrm{m}])$ であり, $x_{k}^{E}, y_{k}^{E}, z_{k}^{E}$ は足部における踵点, 中足点, 末節骨点の外力作用点位置の変位座標值, $x_{k}^{E 0}, y_{k}^{E 0}, z_{k}^{E 0}$ は第 $k$ 番目が外力作用位置に接した瞬間の座標位置であ る. 床面の粘弾性モデルにおける弾性係数および粘性係数については先行研究(Hase and Yamazaki, 2002)に基づく 経験則により，計算が容易となるよう試行錯誤的に決定したものとする．鉛直方向の粘性項については，鉛直方 向の速度が正のとき，すなわち足が床面から離れていくときは作用しないように設定した． $\alpha$ は減衰係数の立ち あがり距離 $0.01[\mathrm{~m}]$ であり, 接触する瞬間の粘性項の不連続性を避けるために線形的に増加寸るように設定した. また，計算コストを低減するためには，微分方程式の差分間隔を大きくすれば良いが精度が減少する，本研究で は，差分間隔を大きくし計算コストと計算精度を両立するために床反力点ごとの 3 次元床反力值の平滑化を成分 ごとにそれぞれ再帰型 IIRディジタルフィルタで行った．計算で使用した 2 次の臨界減衰フィルタ（Critically damped filter）は，バターワースフィルタと比較するとオーバーシュートせずに，立ち上がり時間に優れている特 徵を持つ(Robertson and Dowling, 2003). 次式は設計したフィルタの式である.

$$
f_{k, n}^{E *}=\lambda_{0} f_{k, n}^{E}+\lambda_{1} f_{k, n-1}^{E}+\lambda_{2} f_{k, n}^{E}+\mu_{1} f_{k, n-1}^{E *}+\mu_{2} f_{k, n-2}^{E *}
$$

ここで, $f_{k, n}^{E *}$ はフィルタ後の床反力であり, $\lambda_{0}, \lambda_{1}, \lambda_{2}, \mu_{1}, \mu_{2}$ は各係数, 右下添え字 $n$ は現シミュレーション時点 を示し, $n-1$ は一差分間隔前時点での值である.

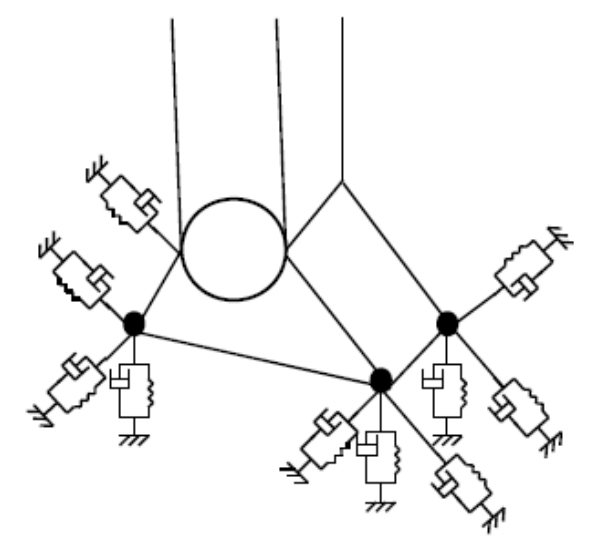

Fig. 3 Floor surface model consisting of spring and damper. Ground reaction force can simply be calculated by penalty method using this model to express linear viscoelastic force.

\section{$2 \cdot 4$ 神経系モデル}

ヒトの歩行運動に関する制御機構として, 本モデルでは定常歩行における自動的な制御機構についてモデル化 を行った. 本研究では, Taga ら(Taga, et al., 1991; Taga, 1994; Taga, 1995)による制御機構モデルを参考にしてモデ ル構築を行った. このモデルは中枢パターン発生器を統合したリズム生成回路により歩行運動の基本的なリズム を生成する.このリズム生成回路は, 上位中枢からの入力として定常入力を与えることで活性化され, リズムを 生成する. リズム生成回路の出力により筋駆動モーメントが刺激され, 筋駆動モーメントから筋群ごとに最適化 計算を行うことで各筋張力を発生し，運動を実現する．さらに，身体各節の状態や床との接地などの情報が感覚 情報として周期的にリズム生成回路にフィードバックされる．これにより, 神経系と身体力学系が協調して, 相 互引き込みが可能となる.

周期的なリズムを生成するパターン発生器は各部位ごとに存在する(Grillner, 1975)と考えられていることから， 
神経モデルであるリズム発生器は各関節の自由度ごとに対応する屈曲・伸展のユニットを配置し, 31 組の回路網, 全身では 62 のユニットで構成される. パターン発生器の全容は明らかになっていないが，モデルの簡単化のた めにこの仮定を用いた. 以下ではこのパターン発生器の数学モデルとしての特徵を表すために神経振動子 (Neural Oscillator）と呼ぶことにする.この各神経振動子は関節モーメントに対応する出力パターンを発生し, 各神経振 動子は抑制結合によって結合される。この神経振動子の結合形式には以下の特徴がある.

(1) 左右の股関節屈伸および上腕部屈伸の神経振動子は相互に抑制されているので, 半周期の位相遅れを持ち, 左右で交互に運動するパターンを生成する.

(2) 歩行運動の基本周期は股関節の神経振動子により形成され，それが他の関節に波及され作用する形式とする. 本研究では, パターン発生器となる神経振動子として Matsuoka による相互抑制モデル(Matsuoka, 1985)を用い た. 1 組の神経振動子について, 2 変数から構成される以下のような連立微分方程式が得られる.

$$
\begin{aligned}
& \tau_{n} \dot{u}_{n}=-u_{n}-\sum_{n^{\prime}} w_{n n^{\prime}} X_{n^{\prime}}-\beta_{n} v_{n}+u_{0 n}+\text { FeedBack }_{n} \\
& \dot{\tau}_{n} \dot{u}_{n}=v_{n}+\chi_{n} \\
& \chi_{n}=\max \left(0, u_{n}\right) \\
& n_{i}=\psi_{n} \chi_{n}-\psi_{n+1} \chi_{n+1}
\end{aligned}
$$

ここで, $u_{n}$ と $\dot{u}_{n}$ は第 $n$ ニューロンの内部状態, $\chi_{n}$ はニューロンの出力, $v_{n}$ はニューロン内の疲労状態, $u_{0 n}$ は 上位中枢からの定常持続入力 (正の一定值), $\tau_{n}$ と $\dot{\tau}_{n}$ は時定数, $\beta_{n}$ はニューロンの疲労状態が内部状態へ与える 影響を表す係数, $w_{n n^{\prime}}$ ' は第 $n$ 神経振動子と第 $n^{\prime}$ 神経振動子間の結合荷重, $\max ()$ は引数の中で最も大きな值を出 力する関数, そしてFeedBack $k_{n}$ は身体力学系からのフィードバック信号である. 最後に, 神経振動子の出力と関 節駆動モーメント換算係数 $\psi_{n}, \psi_{n+1}$ から筋駆動関節モーメント $n_{i}$ を求める. そして, 筇駆動モーメントから筋群 ごとに筋疲労最小化を目的関数とした最適化計算を行うことで各筋張力を発生し，運動を実現する.

身体力学系からのフィードバックは基本的に反射機構を模して, 感覚受容器からの入力を受ける. 歩行の形成 にはリズム生成機構のみならず, 反射系の関与が明らかになっているが, 詳細な反射機構は必ずしも明らかでな い. そこで, 本研究では以下の仮定に基づいてフィードバック経路の構築を行った。

（1）基本的にフィードバックされる力学量（感覚量）は節角度, 角速度および足部が接地しているかどうかの接 地感覚とした。

（2）角度の情報は重力下において運動することを考慮して, 基本的に鉛直軸と節のなす絶対角度を用いる. ただ し, 節の絶対角度を検知する感覚受容器の存在は生理学的に考え難く, 実際には筋紡錘で検出される筋の長さ や収縮速度などがフィードバックされるものと考えられる.しかし, 本モデルでは歩行運動という粗大運動を 対象としていることと複数の体勢感覚の情報を統合すれば, このような角度情報と等価であると考えられるこ とを考慮して，絶対角度のような比較的抽象度の高いフィードバック量を用いた。

(3) フィードバック回路は実歩行との整合性を考慮して試行錯誤的に求めた.

(4) 各関節の屈曲・伸展の神経振動子には同一の形式のフィードバック経路に符号が反転した形で入力される. すなわち，屈曲・伸展のいずれかの神経振動子がフィードバック信号により興奮（または抑制）を受けてい る場合，他方は同一の強さの抑制（または興奮）の信号を受ける.このことにより，主動筋と逆の動きをす る拮抗筋の活動を抑制できる.

\section{$2 \cdot 5$ 神経系パラメータ探索のための目的関数}

シミュレーションにおいては, 差分間隔 0.4 [ms]で Runge-Kutta-Gill 法を用いて連立微分方程式の数值積分を行 った. サンプリング間隔が非常に短い理由は, 床面モデルの弾性係数が大きいことと, 足部の末節趾が非常に小 さな質量と慣性モーメントで構成されているために計算が発散しやすいからである. シミュレーションは 5 歩行 周期(10 歩分)について行った。初期姿勢は，それぞれの歩行様式を再現するように初期角度を設定した．また， つまずきを防止するように大腿の屈曲や下腿の伸展角度を通常の歩行様式より大きくした.

他方, 本モデルで歩行を生成するには神経系パラメータの適切な調整が必要となる. 多峰性の目的関数に対し て導関数の算出を必要とせず, 㛜密な最適解の歩行様式通りにヒトが運動することは困難なため, 大変数で大域 
的な準最適解の探索に適した遺伝的アルゴリズムを用いて探索計算を行った.

歩行の目的関数は関節トルクの 2 乗和最小など様々なものが提案されている(Xiang, et al., 2010)が，統一的な指 標は存在していないといえる. 最初に, 従来使用されていた足部モデル（以下，従来モデルと記する）で用いた 目的関数を式(10)に示寸.

$$
J=\left\{\begin{array}{l}
a_{1} \times \text { step cnt }+a_{2} \times D_{x}-a_{3} \times\left|D_{y}\right|, \text { stride cnt }<5 \\
a_{4}+\frac{a_{5}}{50 \times \text { specific power }}-a_{6} \times\left|D_{y}\right|, \text { stride cnt }=5
\end{array}\right.
$$

ここで, 2 種類の目的関数 $J$ において step cht はどちらかの足が接地するごとに值が 1 ずつ増加するものであり, stride c nt は片方の足が接地してからその足が再び接地するごとに值が 1 ずつ増加するものである． $D_{x}$ は腰点の

進行方向移動距離 $[\mathrm{m}] ， D_{y}$ は左右方向移動距離 [m]である. また， $a_{1}, a_{2}, a_{3}, a_{4}, a_{5}, a_{6}$ はそれぞれのパラメータ に対する重み係数である.

目的関数は上式のように既定の歩行周期数（ストライド数）まで歩行運動が達成できるか否かで区分した． 既 定のストライド数に達しない場合は目的関数を歩数と移動距離が最大となるような重み係数を付加したそれらの 重み付き線形和で定義し, 既定のストライド数に達した場合は既定のストライドに達しなかった場合より值が十 分大きくなるような重み係数 $a_{4}$ を付加するようにした. 次式に示す specific power は移動仕事率と呼ばれる指標 である.これは, 移動に要した消費エネルギを移動距離と体重で除した值であり, 二足歩行をはじめとする一般 的な水平移動様式の移動効率を表す指標と考えられている(Gabrielle and Kármán, 1950). また，ヒトが自然に選択 した速度で単位時間当たりの消費エネルギが最小になるという実験的結果(Ralston, 1958)からも，この指標が歩行 運動の第一義的な評価指標となると考えられた。この移動仕事率 specific power は次式によって定義される.

$$
\text { specific power }=\frac{1}{D M g} \int \sum_{m}\left(\dot{E}_{m}+\dot{B}\right) d t
$$

ここで，Dは腰点の移動距離， $M g$ は体重， $m$ は筋番号， $\dot{E}_{m}$ は消費パワー， $\dot{B}$ は内臟などの筋以外で消費され る基礎代謝であり, 両者の和で身体の消費パワーを表す.

式(10)に示した 2 種類の目的関数を切り替える既定の歩行ストライド数について, シミュレーションで計算す るストライド数が少ないと立脚安定性が高いとはいえない. 一方で，ストライド数を多くすると計算コストが増 大寸ることから, 本研究ではシミュレーションにおける既定のストライド数を 5 とした.

さらに, 本研究では式(10)に示した従来モデルでの歩行における目的関数に更なる指標を追加することを考え た. Perry ら(Perry and Burnfield, 1992)によると, 下半身に相当するロコモータには 4 種類の主な機能 (立脚安定性, 移動，衝撃緩衝，省エネルギ）があり，上体に相当寸るパッセンジャーは直立姿勢を保つだけであると報告され ている，従来モデルの目的関数における移動仕事率は移動性と省エネルギの歩行を実現するものであるが，安定 性や衝撃緩衝を満足するような評価指標は考慮されていなかった. そのため, 以下のような指標の追加を行った.

まず，安定性を確保するため, 遊脚期に足趾がつまずかないように, 遊脚中の足趾接触点の高さが一定高さ未 満の場合に減点するようなトウクリアランスペナルティを加えた. 従来モデルではパラメータ探索を行った際に, 途中でつまずく場合や床面と擦れ擦れの位置を足趾が通る場合が多く, 安定性を向上させるために設けた. ここ で，トウクリアランスを設ける根拠をヒトの歩行に及ぼす機能の観点から述べると，二足歩行において特徽的に 生じざるを得ない歩行中の上下方向における重心の偏位が必要以上に大きくなると力学的仕事である消費エネル ギが増加してしまうため, 遊脚期では足部の背屈筋が働き床面に接触しない程度の非常に小さい值の間隔を生じ させ, 重心が不必要に上昇することを抑えて歩行の安定性を維持している(江原, 山本，2002)ことによる. 一般 的なトウクリアランスは 20〜39歳の男性で 12.4 4.5 [mm] (西澤他, 1998)であり, 本モデルでは, 立脚側の足部 がバネとダンパで模した床面により沈み込むため, $7[\mathrm{~mm}]$ 未満のときに減点するよう次式のような式を定めた.

$$
\text { clearance }=\left(0.007-f_{z, k}^{E}\right) / 0.007 \quad \mid f_{z, k}^{E}<0.007
$$


次いで, 以前までの歩行モデルの床反力は鉛直方向ピーク值が実歩行よりも大きくなる欠点を有していた. 歩 行速度 1.3 [m/s] での床反力ベクトルの大きさは 1.25 程度(木村, 神谷, 1982)であり, 衝撃緩衝を行えるように床 反力ベクトルの大きさが 1.25 を超えた際, 減点するように次式のような式を定めた.

$$
\text { overload }=\int\left\{\left(\sum_{m} \frac{f_{k}^{\tau}}{M g}\right)-1.25\right\} d t \quad \mid\left\{\left(\sum_{m} \frac{f_{k}^{\tau}}{M g}\right)-1.25\right\}>0
$$

これらの指標となる目的関数をひとまとめにし，混成化した最終的な目的関数 $J$ は以下のような式で表される. ここでも， $a_{1}, a_{2}, a_{3}, a_{4}, a_{5}, a_{6}, a_{7}, a_{8}$ はそれぞれのパラメータに対する重み係数である. 重み係数の決定方法は式 (10)と同様であり, 各項の值のオーダーや単位の違いを考慮し, それらが均一となるように重み係数を付加した.

$$
J=\left\{\begin{array}{l}
a_{1} \times \text { step cnt }+a_{2} \times D_{x}-a_{3} \times\left|D_{y}\right|, \text { stride cnt }<5 \\
a_{4}+\frac{a_{5}}{50 \times \text { specific power }}-a_{6} \times\left|D_{y}\right|-a_{7} \times \text { overload }-a_{8} \times \text { clearance, stride cnt }=5
\end{array}\right.
$$

\section{$2 \cdot 6$ モデルの評価}

本研究における提案モデルの評価を行うため, 従来モデルとの比較を行った。 すなわち, 従来モデルとは足部 の関節がすべて固定され，足部が 1 節で構成された前足部固定モデルと呼ばれるものであり，歩行の目的関数は 式(10)で定義された移動仕事率を中心としたものを用いた. 他方, 提案モデルでは足部に距舟関節, 踵立方関節, 中足趾節関節の関節自由度を追加した図 2 に示したような精密足部モデルとして, 歩行の目的関数も式(14)によ る新たな評価基準の混成化を行ったものを用いた. 次章では, 双方の足部モデルならびに目的関数について改良 前の両者と改良後の両者を組み合わせた場合のシミュレーション結果を相互比較し, ヒトの歩行における改善効 果の有効性を検証する.

\section{3. 結果および考察}

\section{$3 \cdot 1$ 歩行様式}

図 4 に示寸描画は，第 2 章 5 節に示したような新たに指標を混成化し改良した式(14)の目的関数を適用した精 密足部モデル（以下，精密足部モデルと記する）のスティックピクチヤによるシミュレーション結果である. 赤 色の線分で表示している部分が身体の右部位であり, 身体の中央および身体の左部位は緑色の線分で表示した。

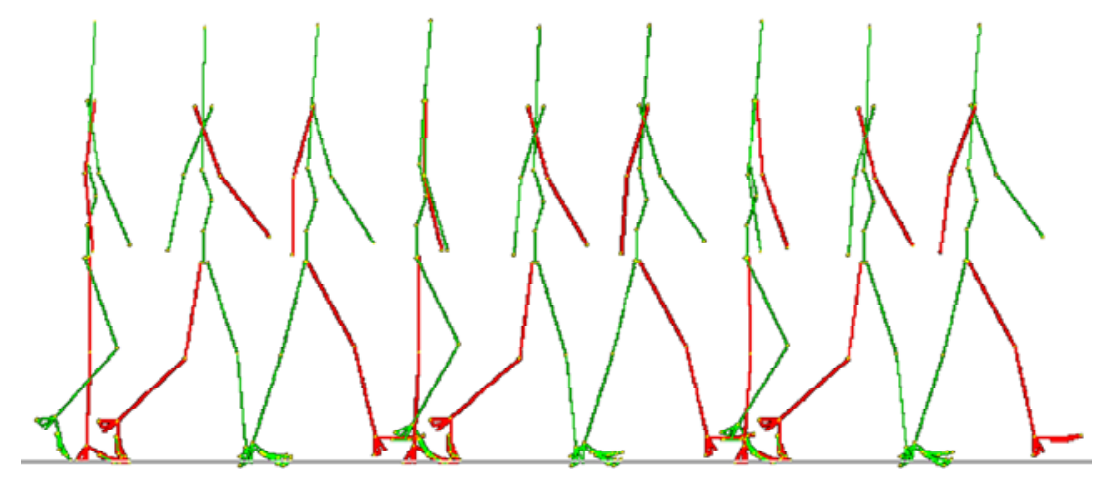

Fig. 4 Simulation result based on the stick picture using the precise foot segment model. Time interval is 0.35 [s].

衣笠らの実験結果(衣笠他，1994)によると成人男性では歩行速度 $1.41[\mathrm{~m} / \mathrm{s}]$, ストライド長 $1.42[\mathrm{~m}]$, 歩行周波 数 $0.99[\mathrm{~Hz}]$ となっており, 精密足部モデルでは歩行速度 $1.33[\mathrm{~m} / \mathrm{s}]$, ストライド長 $1.40[\mathrm{~m}]$, 歩行周波数 $0.95[\mathrm{~Hz}]$, 移動仕事率 0.391 , 式(10)に示す従来の目的関数を適用した前足部固定モデル (以下, 前足部固定モデルと記する) では歩行速度 $1.25[\mathrm{~m} / \mathrm{s}]$, ストライド長 $1.35[\mathrm{~m}]$, 歩行周波数 $0.93[\mathrm{~Hz}]$, 移動仕事率 0.412 となった. ここで, 双 方の結果を比較すると, 前足部固定モデルでは, 歩行速度の低下, ストライド長の減少と移動仕事率の悪化が見 
られた．その理由としては，精密足部モデルの場合と異なり滑らかな足部の変形機構による床反力の有効活用が 不可能であったことが考えられる. 他方, 精密足部モデルでは, 実験より歩行速度が遅くなり, ストライド長, 移動仕事率ともに前足部固定モデルと同様に実験結果よりは小さくなったが，前足部固定モデルの場合と比較し てそれぞれの值がより近くなったことが確認でき, 歩行には個人差が多分に含まれるので十分に妥当な結果であ るといえる.

なお，本シミュレーション結果は式(10)において $a_{1}=2, a_{2}=1, a_{3}=1, a_{4}=50, a_{5}=800, a_{6}=5$ と決定した場 合における前足部固定モデル適用時の結果, ならびにそれらに加えて $a_{1} \sim a_{6}$ を同様の值とした上で $a_{7}=100, a_{8}$ $=5$ と決定した場合における精密足部モデル適用時の結果であり, 重み係数のうち $a_{7}$ の值が非常に大きいことか らも，床反力ベクトルの衝撃緩衝による効果が大きくなり実歩行により近くなったことが考えられる．よって， 重み係数を適用寸る観点からも，提案した指標の混成化による目的関数は有用であるといえる.

\section{$3 \cdot 2$ 床反力}

図 5 に精密足部モデル, 前足部固定モデルおよび計測值(Taga, 1995)の床反力值を自重で除した正規化床反力を 示す. 図 5 より, 前足部固定モデルは床反力を評価していないため, 初期接地での鉛直方向床反力が大きくなっ たことがわかる. また, 立脚期終期の能動的な蹴り出しが行えないために床反力が小さくなった. これらの結果 は前節にも反映されているといえ, 改良前の足部モデルを用いた場合における計測值の再現性の低さを表してい るといえる. 他方, 精密足部モデルは初期接地を除いて, 定量的にも定性的にも前足部関節の能動的な蹴り出し や関節角度変化により妥当な結果を示した，ここで，初期接地時の床反力が大きくなったことについては，床面 モデルをバネとダンパで模擬したことにより，初期接地時の粘性係数の立ちあがりによるものといえる.

また, 図 5 (c)より初期接地での鉛直方向床反力が前足部固定モデルと異なり床反力ベクトルの閾值である 1.25 よりも小さくなっており, 床反力においては鉛直方向成分の值が著しく大きいことを考慮すると, 前節で述べた ように, 重み係数によって床反力ベクトルの衝撃緩衝が大きくなったためにこのような結果が生じたと考えられ, 床反力波形の観察からも混成化した目的関数の有効性を示寸ことができたといえる.

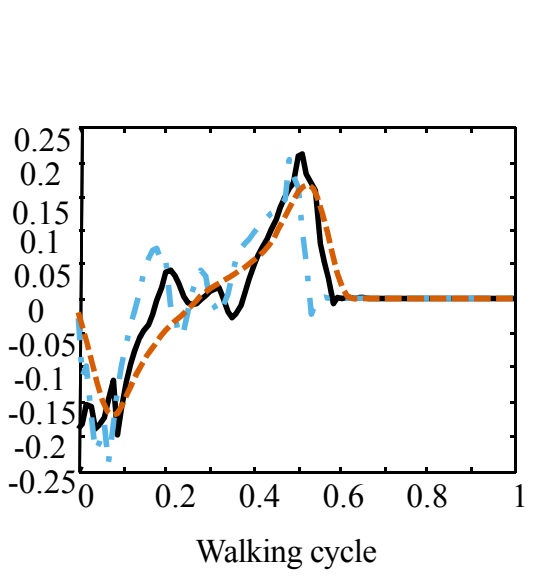

(a) Horizontal direction

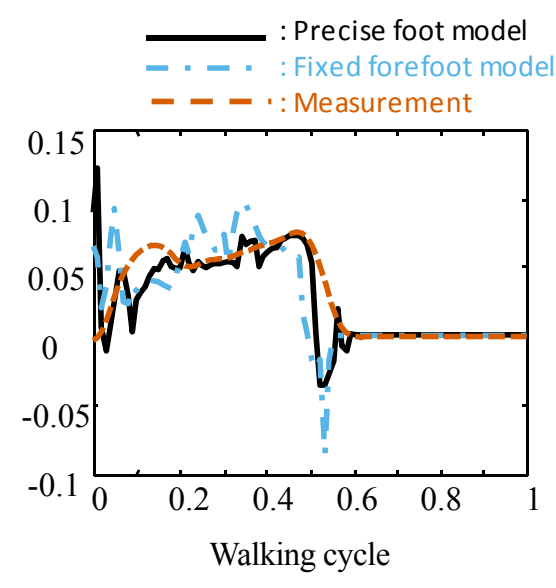

(b) Lateral direction

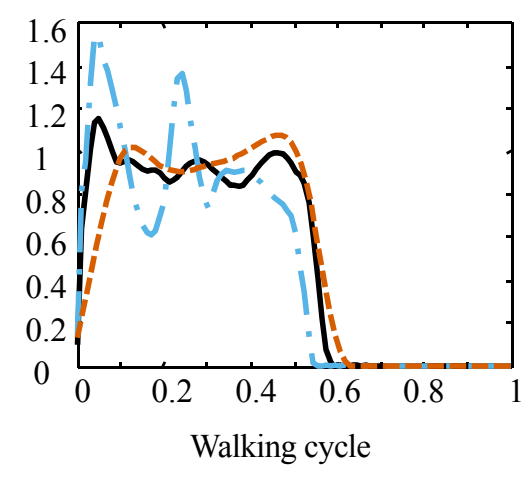

(c) Vertical direction

Fig. 5 Normalized ground reaction forces of compared two foot models and the measurement value along a walking cycle.

Black line is precise foot segment model, blue line is fixed forefoot model and brown line is measurement value.

\section{$3 \cdot 3$ 関節角度}

図 6 に下肢関節の相対角度変化を計測值(Taga, 1995) と合わせて示す. 図 6 から, 股関節と膝関節の屈伸は実際 の歩容を再現していることがわかる．特に，膝関節の立脚初期で発生する二重膝作用は重心の上下動の低減と衝 撃の緩和を行い，精密足部モデルに適用したものである混成化した改良後の目的関数において床反力の閾值を設 けることによって初めてこの二重膝作用が見られるようになった．前節からの流れを考慮すると，鉛直方向床反 力の衝撃緩衝を実現でき床反力の初期ピークが低減されたためにこのような現象が生じたと考えられる. 他方, 改良前の目的関数を適用した前足部固定モデルでは初期接地時の床反力が大きく二重膝作用が行えないなど, 膝 
関節より下の部位に違いが見られるといえる。これらより，改良された足部モデルおよび目的関数の両面からの 相互比較により,それらの複合的な相乗効果として計測值に近いシミュレーション結果が得られたと考えられる.

また，図 7 に足部関節の相対角度変化を計測值と合わせて示す．床面と接触する距腿関節と母趾の中足趾節関 節は計測值との差異が大きくなる結果となった。これは，精密足部モデルでは床面をバネとダンパで模擬してい ることによって，実際の歩容とは異なり足部が沈み込み，急激な角度変化を生じることにより接地が不安定にな りやすいためと考えられる．しかし，床反力波形は定性的にも定量的にも実歩行を精度よく再現しており，足部 の質量および慣性モーメントは他の部位に比べて非常に小さいため，身体全体に及ぼす影響は小さいといえる.

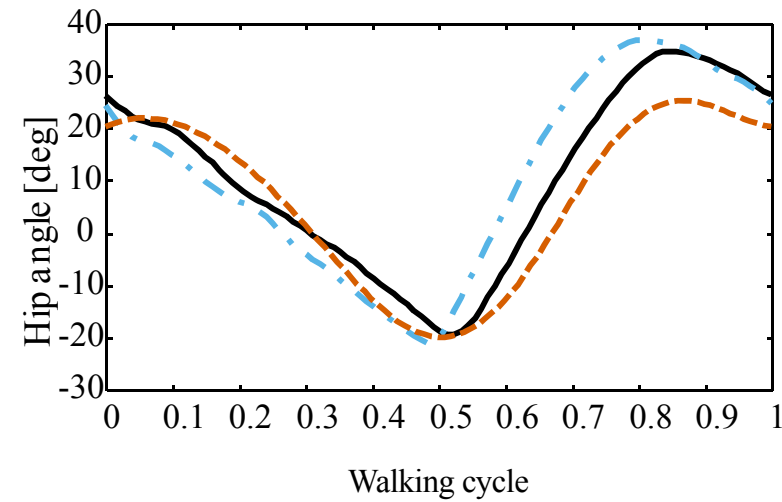

(a) Hip angle

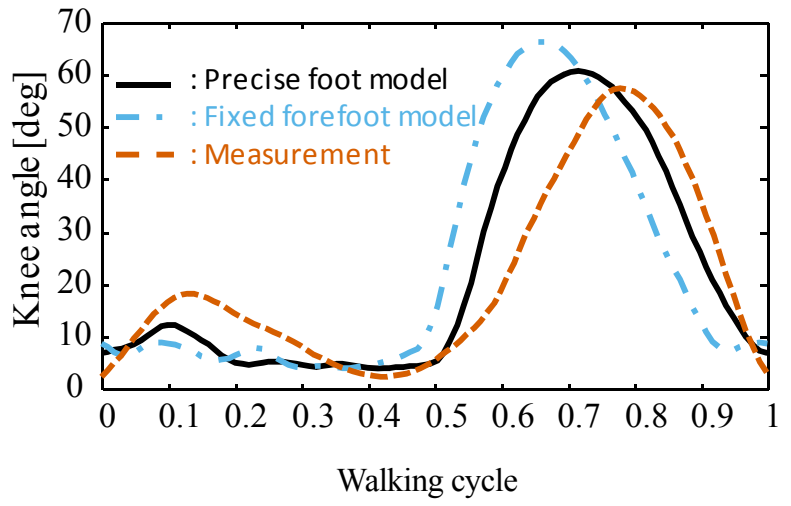

(b) Knee angle

Fig. 6 Hip and knee joint angles as comparative variations in cases of two foot models and the measurement value along a walking cycle. Black line is precise foot segment model, blue line is fixed forefoot model and brown line is measurement value.

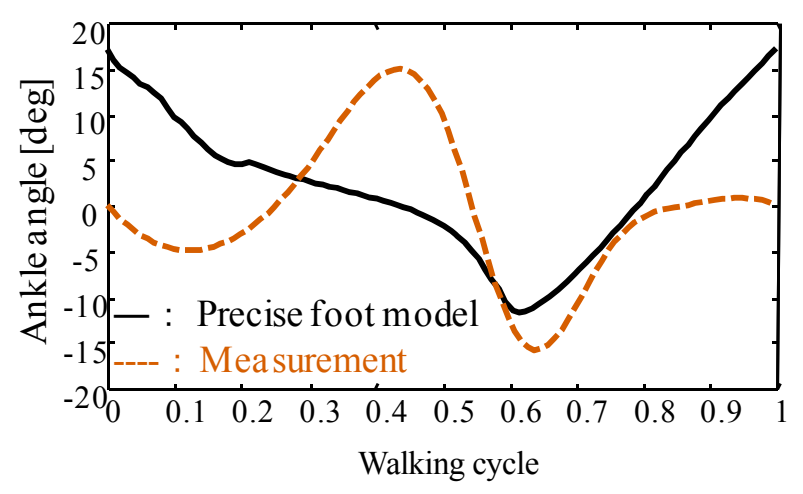

(a) Ankle angle

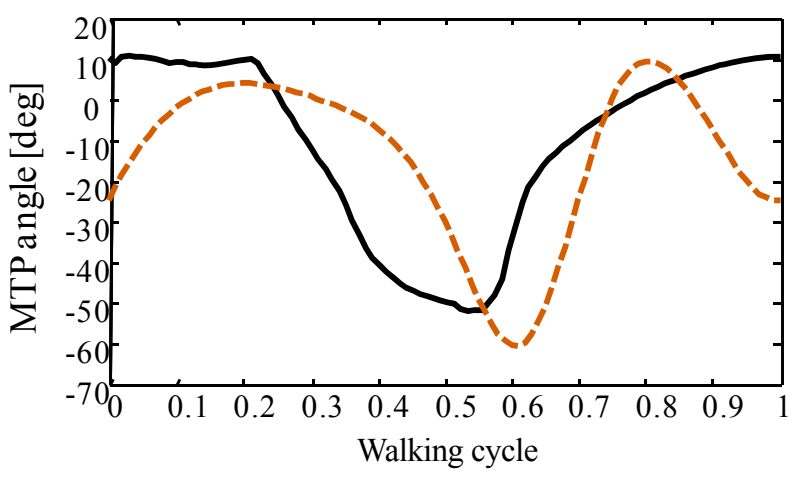

(b) MTP (Metatarsophalangeal) angle

Fig. 7 Joint angles of foot as comparative variations in cases of precise foot segment model and the measurement value along a walking cycle. Black line is precise foot segment model and brown line is measurement value.

\section{$3 \cdot 4$ 力学的エネルギの推移}

図 8 に精密足部モデルと前足部固定モデルにおける力学的エネルギの推移を示す. 図 8 から, 前足部固定モデ ルでは前足部の角度変化が行えないため, 精密足部モデルより位置エネルギのピーク差が少なく, また両脚支持 期での位置エネルギが滑らかでないなど安定性が低下した。一方，足部を精密化させることで床反力作用点と床 反力の大きさにより柔軟な足部関節の角度変化が行えるようになり, 歩行中の位置エネルギの変化をより滑らか にした，そして，全ての消費エネルギに占める位置エネルギ，運動エネルギおよび筇消費エネルギの割合を移動 仕事率の最小化から適正化することで，探索計算により生成された精密足部モデルでの歩行様式は実歩行を精度 良く再現しており，生体力学的に妥当であるといえる.

以上のことから，本研究では新たに開発，提案した精密足部モデルに加えて，移動仕事率の最小化，トウクリ アランスの確保ならびに床反力の閾值を組み込み混成化した目的関数を適用したヒトの 3 次元歩行シミュレーシ ヨンを行い，従来の前足部固定モデルおよび目的関数を適用した場合と比較することにより，歩行パラメータに 基づき実際のヒトにより近い歩容が得られたことが確認でき, 足部の精密化, 目的関数の混成化の双方による歩 行シミュレーションモデルの有効性を検証できたといえる. 


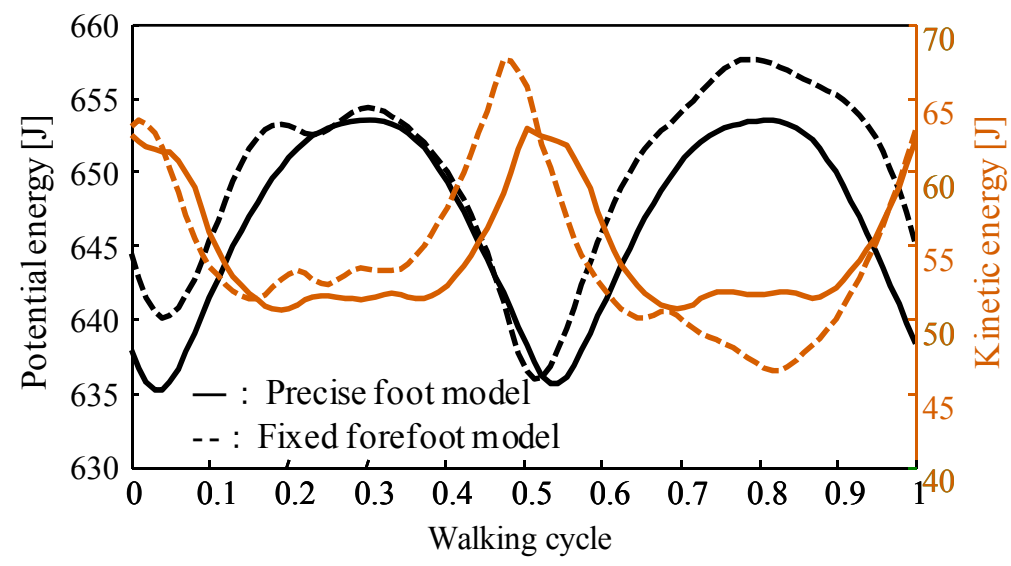

Fig. 8 Transition of mechanical energies as potential energy and kinetic energy in cases of two foot models along a walking cycle. Black line is potential energy and brown line is kinetic energy.

\section{4. 結言}

本研究では，距舟関節，踵立方関節および中足趾節関節を付加することでヒトの足部を精密化し，神経系パラ メータを探索するための目的関数を立脚安定性, 移動, 衝撃緩衝, 省エネルギの観点から移動仕事率の最小化, トウクリアランスおよび床反力ペナルティとした上で，それらの混成化に基づきヒトの歩行モデルを開発した. その際, 従来モデルである前足部固定モデルと異なる精密足部モデルの力学的構造，ならびにそのモデルに適用 したものである混成化した新しい目的関数に基づき実現した前足部関節の能動的な䟣り出しおよび角度変化によ り位置エネルギと運動エネルギの相互変換の容易化, 床反力ペナルティによる床反力波形の再現および移動仕事 率の最小化から各エネルギを適正化することによって, 生体力学的に妥当なヒトの歩行様式を再現することに成 功した. 特に, 衝撃緩衝のために設けた床反力ペナルティの影響により, 床反力波形が定量的な形でも再現でき るようになり，膝関節の二重膝作用が新たに観察されるようになるなど歩行様式の妥当性を向上させた.

\section{文献}

江原義弘，山本澄子，ボディダイナミクス入門＼cjkstart歩き始めと歩行の分析 (2002), pp. 149-167, 医歯薬出版.

Gabrielle, G. and Kármán, T. V., What price speed, Mechanical Engineering, Vol. 72, No. 10 (1950), pp. 775-781.

Grillner, S., Locomotion in vertebrates: central mechanisms and reflex interaction, Physiological Reviews, Vol. 55, No. 2 (1975), pp. 367-371.

長谷和徳，西口純也，山崎信寿，3 次元筋骨格系と階層的神経を有する 2 足歩行モデル，バイオメカニズム, Vol. 17 (2000), pp. 187-198.

Hase, K. and Yamazaki, N., Computer simulation study of human locomotion with a three-dimensional entire-body neuro-musculo-skeletal model : I. acquisition of normal walking, JSME International Journal, Series C, Vol. 45, No. 4 (2002), pp. 1040-1050.

木村賛，神谷正明，速度変化に伴いヒトの歩行がどう変わるか，バイオメカニズム，Vol. 6 (1982), pp. 69-79.

木村賛, 木村忠直, 歩行の進化と老化 2.1 ヒトの歩行に関与寸る骨格筋の加齢変化, 人間科学全書研究報告シ リーズ 1 (2002), pp. 161-178, てらぺいあ.

衣笠隆，長崎浩，伊東元，橋詰謙，古名丈人，丸山仁司，男性（18～33 歳）を対象とした運動能力の加齢変化の 研究, 体力科学, Vol. 43 (1994), pp. 343-351.

Kirsten, G. N., Gehen verstehen ganganalyse in der physiotherapie (2003), Georg Thieme Verlag.

Matsuoka, K., Sustained oscillations generated by mutually inhibiting neurons with adaption, Biological Cybernetics, Vol. 52 (1985), pp. 345-353.

McKenna, M. and Zeltzer, D., Dynamic simulation of autonomous legged locomotion, Computer Graphics, Vol. 24, No. 4 (1990), pp. 29-38.

Moore, M. and Wilhelms, J., Collision detection and response for computer animation, Computer Graphics, Vol. 22, No. 4 
(1988), pp. 289-298.

西澤哲，長崎浩，古名丈人，奥住秀之，杉浦美穂，伊東元，藤田祐樹，地域高齢者を対象にした歩行時のフット クリアランスに関する研究，バイオメカニズム，Vol. 14 (1998), pp. 69-79.

Perry, J. and Burnfield, J., Gait analysis: normal and pathological function (1992), Slack Incorporated.

Ralston, H. J., Energy-speed relation and optimal speed during level walking, Internationale Zeitschrift für Angewandte Physiologie, Vol. 17 (1958), pp. 277-283.

Robertson, D. G. and Dowling, J. J., Design and responses of butterworth and critically damped digital filters, Journal of Electromyography and Kinesiology, Vol. 13, No. 6 (2003), pp. 569-573.

鈴木隆雄, 河内まき子, 楠本彩乃, 西澤哲, 山崎信寿, 足の事典 (1999), pp. 1-28, 朝倉書店.

Taga, G., Yamaguchi, Y., and Shimizu, H., Self-organized control of bipedal locomotion by neural oscillators in unpredictable environment, Biological Cybernetics, Vol. 65 (1991), pp.147-159.

Taga, G., Emergence of bipedal locomotion through entrainment among the neuro-musculo-skeletal system and the environment, Physica D - Special Issue on Constructive Complexity and Artificial Reality, Vol. 75 (1994), pp.190-208.

Taga, G., A model of the neuro-musculo-skeletal system for human locomotion, Biological Cybernetics, Vol.73, No. 2 (1995), pp. 97-111.

高嶋孝倫, 藤本浩志, 高西淳夫, 単純化された足部モデルによる足アーチの粘弾性解析, 日本機械学会論文集 C 編, Vol. 67, No. 663 (2003), pp. 173-178.

Xiang, Y., Arora, J. S. and Abdel-Malek, K., Physics-based modeling and simulation of human walking: a review of optimization-based and other approaches, Structural and Multidisciplinary Optimization, Vol. 42, No. 1 (2010), pp. 1-23.

\section{References}

Ehara, Y. and Yamamoto, S., Introduction to body dynamics: analysis of begin walking and gait (2002), pp. 149-167, Ishiyaku Publishers, Inc (in Japanese).

Gabrielle, G. and Kármán, T. V., What price speed, Mechanical Engineering, Vol. 72, No. 10 (1950), pp. 775-781.

Grillner, S., Locomotion in vertebrates: central mechanisms and reflex interaction, Physiological Reviews, Vol. 55, No. 2 (1975), pp. 367-371.

Hase, K., Nishiguchi, J. and Yamazaki, N., Model of human walking with three-dimensional musculo-skeletal system and hierarchical neuronal system, Biomechanism, Vol. 17 (2000), pp. 187-198 (in Japanese).

Hase, K. and Yamazaki, N., Computer simulation study of human locomotion with a three-dimensional entire-body neuro-musculo-skeletal model : I. acquisition of normal walking, JSME International Journal, Series C, Vol. 45, No. 4 (2002), pp. 1040-1050.

Kimura, T. and Kamiya, M., Human walking in relation to speed, Biomechanism, Vol. 6 (1982), pp. 69-79 (in Japanese).

Kimura, T. and Kimura, T., Evolution and aging of gait (2002), pp. 161-178, Therapeia (in Japanese).

Kinugasa, T., Nagasaki, H., Ito, H., Hashizume, K., Furuna, T. and Maruyama, H., Effect of aging on motor ability in men aged 18 to 83 years, The Japanese Journal of Physical Fitness and Sports Medicine, Vol. 43, No. 5 (1994), pp. 343-351 (in Japanese).

Kirsten, G. N., Gehen verstehen ganganalyse in der physiotherapie (2003), Georg Thieme Verlag.

Matsuoka, K., Sustained oscillations generated by mutually inhibiting neurons with adaption, Biological Cybernetics, Vol. 52 (1985), pp. 345-353.

McKenna, M. and Zeltzer, D., Dynamic simulation of autonomous legged locomotion, Computer Graphics, Vol. 24, No. 4 (1990), pp. 29-38.

Moore, M. and Wilhelms, J., Collision detection and response for computer animation, Computer Graphics, Vol. 22, No. 4 (1988), pp. 289-298.

Nishizawa, S., Nagasaki, H., Furuna, T., Okuzumi, H., Sugiura, M., Ito, H. and Fujita, Y., Foot clearance during walking of older adults in the community, Biomechanism, Vol. 14 (1998), pp. 69-79 (in Japanese).

Perry, J. and Burnfield, J., Gait analysis: normal and pathological function (1992), Slack Incorporated.

Ralston, H. J., Energy-speed relation and optimal speed during level walking, Internationale Zeitschrift für Angewandte Physiologie, Vol. 17 (1958), pp. 277-283. 
Robertson, D. G. and Dowling, J. J., Design and responses of butterworth and critically damped digital filters, Journal of Electromyography and Kinesiology, Vol. 13, No. 6 (2003), pp. 569-573.

Suzuki, T., Kouchi, M., Kusumoto, A., Nishizawa, S. and Yamazaki, N., Encyclopedia of foot (1999), pp. 1-28, Asakura Publishing Co., Ltd (in Japanese).

Taga, G., Yamaguchi, Y., and Shimizu, H., Self-organized control of bipedal locomotion by neural oscillators in unpredictable environment, Biological Cybernetics, Vol. 65 (1991), pp.147-159.

Taga, G., Emergence of bipedal locomotion through entrainment among the neuro-musculo-skeletal system and the environment, Physica D - Special Issue on Constructive Complexity and Artificial Reality, Vol. 75 (1994), pp.190-208.

Taga, G., A model of the neuro-musculo-skeletal system for human locomotion, Biological Cybernetics, Vol.73, No. 2 (1995), pp. 97-111.

Takashima, T., Fujimoto, H. and Takanishi, A., Analysis of the human foot arch viscoelasticity using the simple model of the arch support elements, Transactions of the Japan Society of Mechanical Engineers, Series C, Vol. 67, No. 663 (2003), pp. 173-178 (in Japanese).

Xiang, Y., Arora, J. S. and Abdel-Malek, K., Physics-based modeling and simulation of human walking: a review of optimization-based and other approaches, Structural and Multidisciplinary Optimization, Vol. 42, No. 1 (2010), pp. 1-23. 